\title{
Distribution of juvenile Uca pugnax and U. pugilator across habitats in a South Carolina estuary, assessed by molecular techniques
}

\author{
Matthew E. Behum ${ }^{1}$, Renae J. Brodie ${ }^{2, *}$, Joseph L. Staton ${ }^{3}$ \\ ${ }^{1}$ Marine Science Program, University of South Carolina, 712 Main Street, Columbia, South Carolina 29208, USA \\ ${ }^{2}$ Department of Biology, University of South Carolina, 700 Sumter Street, Columbia, South Carolina 29208, USA \\ ${ }^{3}$ Department of Natural Resources, University of South Carolina, 801 Carteret Street, Beaufort, South Carolina 29902, USA
}

\begin{abstract}
Uca pugnax and U. pugilator are common fiddler crabs in salt marshes on the Atlantic coast of the United States. As adults, U. pugnax frequent muddier, vegetated (typically Spartina alterniflora) substrate while $U$. pugilator usually occupy sandier, open habitats. It is unclear where juvenile $U$. pugnax and $U$. pugilator reside because the early crab stages of these species are difficult to identify by simple gross morphology. Using a novel restriction fragment length polymorphism (RFLP) protocol to distinguish postlarval U. pugnax and U. pugilator, we studied their distribution along a horizontal gradient in the North Inlet Estuary, South Carolina. We collected juvenile crabs along transects at 3 different sites that spanned $S$. alterniflora-covered mud and open sand habitats with adult populations of $U$. pugnax and $U$. pugilator, respectively. Over $75 \%$ of the juveniles collected were $U$. pugnax, showing greater recruitment by this species. $U$. pugnax juveniles of all sizes preferred the same muddy habitat occupied by adults, but habitat preferences of juvenile U. pugilator varied by site. Generally, U. pugilator displayed a shift in distribution from $S$. alterniflora cover to sandier habitat during early juvenile stages. The younger stages may prefer $S$. alterniflora-covered, muddier habitat because it provides better cover from predators, or so that they can avoid displacement by currents during high tides; alternatively, they may be able to feed better on muddy sediment. U. pugilator develops specialized mouthparts to scrape organic matter from larger sand grains, but these are not present in early juveniles nor in $U$. pugnax juveniles. Although young juvenile $U$. pugnax strongly favored $S$. alterniflora cover, older juveniles (those large enough to dig burrows for protection) were occasionally found in sandier habitat with $U$. pugilator.
\end{abstract}

KEY WORDS: Uca pugnax $\cdot$ U. pugilator - Postlarval settlement $\cdot$ Restriction fragment length polymorphism $\cdot$ RFLP

\section{INTRODUCTION}

Most research on larval settlement by invertebrates has been done on species with sessile adults (Hadfield 1986, O'Connor 1991, 1993). The distribution of sessile adults is determined directly by where larvae settle and juveniles survive. This is not the case for mobile organisms, which may migrate as juveniles to adult habitats after settling elsewhere as larvae.

We examined the distribution of the fiddler crabs Uca pugnax and U. pugilator, which have planktonic larvae and are highly motile as benthic adults, to study habitat selection and migration. These species are found, often at high density, in intertidal marsh habitats from Cape Cod, Massachusetts to Northern Florida and, for U. pugilator, through the eastern Gulf of Mexico, USA, where they strongly affect energy flow and nutrient cycling (Crane 1975, Montague 1982, Hunter \& Feller 1987, Petit \& Bildstein 1987, Watts 1988, Johnson et al. 1990).

Although the adults of these fiddler crab species have been fairly well-studied (e.g. Palmer 1989, Winger 
et al. 1990, Frix et al. 1991, Mangum 1993, Levinton \& Judge 1993, Land \& Layne 1995, Reddy \& Fingerman 1995, Thurman 2002, 2003), comparatively little is known about their larval, postlarval. and juvenile stages, because they cannot be identified until the juveniles reach $\sim 4$ to $5 \mathrm{~mm}$ carapace width (O'Connor 1990a, 1993). This has been a consistent frustration for researchers studying the larval dispersal and settlement of these important estuarine crabs.

Ovigerous female Uca spp. typically release larvae during nocturnal spring tides which facilitates their export from estuaries to the coastal ocean (Christy \& Stancyk 1982, Houser \& Allen 1996) where they develop. However, Uca spp. zoeae of all stages have been found within the expansive estuarine systems of the Chesapeake (Sandifer 1973) and Delaware (Epifanio et al. 1988) bays. Studies of the timing of larval release, larval dispersal and the reinvasion of estuaries by $U c a$ megalopae have grouped larvae into 1 'Uca spp.' category (Christy 1982, Christy \& Stancyk 1982, Jones \& Epifanio 1995, Christy \& Morgan 1998).

Megalopae of both species settle and metamorphose in response to chemical cues from conspecific adults that may be present in both the seawater and on the sediment (Christy 1989, O'Connor 1991, O'Connor \& Gregg 1998, O'Connor \& Judge 1999). However, it is not known if the megalopae settle directly and only in habitats occupied by conspecific adults. Uca pugilator adults generally occupy sandy, coarse substrate, while $U$. pugnax adults frequent habitats often adjacent to $U$. pugilator, consisting of muddier, finer-grained sediment (Crane 1975, O'Connor 1993). O'Connor (1993) compared early juvenile settlement habitats of $U$. pugnax and $U$. pugilator with the habitats of conspecific older juveniles and adults along an intertidal gradient at a single marsh site at the mouth of the Newport River, North Carolina. She found no significant differences between the vertical distributions of early settlers (identified by rearing) and those of older conspecifics, and concluded that $U$. pugnax and $U$. pugilator settled directly into conspecific adult habitats.

The purpose of the present study was to determine if juvenile Uca pugnax and $U$. pugilator occupy the same habitats as their conspecific adults when these habitats are at the same tidal height. We conducted our study at 3 different locations in the North Inlet Estuary, South Carolina. The scope of O'Connor's (1993) study was limited to 1 site by the time-consuming method of rearing juveniles to determine their specific identity. We overcame this limitation by using a novel restriction fragment length polymorphism (RFLP) protocol, which allowed us to quickly and easily identify a large number of juvenile crabs from the 3 study sites.

\section{MATERIALS AND METHODS}

RFLP protocol. DNA amplification, sequencing and RFLP profiling: Nuclear DNA from individual, adult crabs was extracted using the DNeasy ${ }^{\circledR}$ tissue protocol (Qiagen) for approximately $3 \mathrm{mg}$ tissue (wet weight) eluted in a final $100 \mu \mathrm{l}$ buffer volume. Small aliquots of extracted nucleic acids (typically $1 \mu \mathrm{l}$ ) were used as templates for polymerase chain reaction (PCR) amplification (Saiki et al. 1988). Amplifications used the following conditions: $50 \mathrm{mM} \mathrm{KCI}, 10 \mathrm{mM}$ Tris- $\mathrm{HCl}$, $\mathrm{pH}$ 8.3, 3.0 $\mathrm{MM} \mathrm{MgCl}_{2}, 200 \mu \mathrm{M}$ dNTP (Pharmacia), 5 pmol forward and reverse primer, and 1 Unit Taq DNA polymerase (Promega) in $50 \mu$ l total volume. Amplifications used primers internal transcribed spacer (ITS)-1F (CAC ACC GCC CGT CGC TAC TAC CGA TT) and ITS-1R (ATC GAC CCA TGA GCC GAG TGA TC) described in Schizas et al. (1999). Template DNA and negative controls were initially denatured at $96^{\circ} \mathrm{C}$ for $3 \mathrm{~min}$ followed by 35 cycles of $94^{\circ} \mathrm{C}$ for $15 \mathrm{~s}$, $55^{\circ} \mathrm{C}$ for $45 \mathrm{~s}$ and $72^{\circ} \mathrm{C}$ for $60 \mathrm{~s}$.

Prior to sequencing, products were purified by polyethylene glycol precipitation (Kusukawa et al. 1990). An aliquot (200 to $500 \mathrm{ng}$ ) of the purified PCR product was used as template for fluorescent sequencing using PRISM ${ }^{\mathrm{TM}} 3.0$ (Applied Biosystems) chemistry, labeled with Big Dye ${ }^{\mathrm{TM}}$ terminators (dideoxynucleotides), and the products were sequenced in both directions. Standard procedures were followed, except that the terminator chemistry was diluted by half using an equal volume diluent buffer $(0.4 \mathrm{M}$ Tris $\mathrm{pH}$ 9.0, $10 \mathrm{mM} \mathrm{MgCl}_{2}$, B. Roe pers. comm.) and reaction volume at $10 \mu \mathrm{l}$. Sequencing reactions were analyzed on an ABI 377XL sequencer (Applied Biosystems) using $4.5 \%$ acrylamide gels. Complementary sequence strands were assembled using Sequencher 4.1 $1^{\mathrm{TM}}$ (Gene Codes).

From each Uca species (including the freshwatertolerant species, $U$. minax), 8 individuals were sequenced and aligned (Table 1). Within-species variant sites were disregarded, and the remaining variant sites among species could be analyzed by digestion with HpaII restriction enzyme (New England BioLabs) and electrophoresis on a $3 \%$ agarose gel in tris-borateEDTA buffer.

Identification of unknown species: Whole, ethanolpreserved larvae, megalopae, or first juvenile stage crabs were individually ground with disposable microtube pestles and extracted using the DNeasy ${ }^{\circledR}$ tissue protocol (Qiagen) and also eluted in a final buffer volume of $50 \mu \mathrm{l}$ (for smaller zoeal stages), $100 \mu \mathrm{l}$ (for megalopae), or $200 \mu \mathrm{l}$ (for later juvenile stages). PCR followed the same cycling profile and used the same primers as for adult templates, but was optimized to 25 cycles and a $20 \mu$ l total volume, including $1 \mu$ l of the 
eluted template. We used $6 \mu \mathrm{l}$ of each $20 \mu \mathrm{l}$ PCR directly in a restriction digest (1 unit HpaII in $15 \mu \mathrm{l}$ total volume) that was incubated for $2.5 \mathrm{~h}$ at $37^{\circ} \mathrm{C}$. Restriction fragments (RFLPs) for each individual were

Table 1. Uca spp. Consensus sequences for $9 U$. minax, $5 U$. pugnax and $5 U$. pugilator. Boldface letters represent cut sites (CCGG) for HpaII restriction endonuclease for RFLP analysis. Restriction and comparisons of the HpaII enzyme decipher between species: *: distinguishes $U$. minax from $U$. pugnax (but not from $U$. pugilator); +: distinguishes $U$. pugnax from $U$. minax and $U$. pugilator; \$: distinguishes $U$. pugilator from $U$. minax and $U$. pugnax; N: distinguishes an undetermined base; -: reflects inserted gaps ('indels'); Y: pyrimidines of $\mathrm{C}$ or $\mathrm{T}$ distinction; $\mathrm{W}$ weak bonds involving $\mathrm{A}$ or $\mathrm{T}$ in 2-hydrogen molecules

$\begin{array}{ll}\text { U. minax } & \text { CCGGGCCCACGCGGTTCGCCGCTGGGCATTCGGCGCCTCGAGCTGACGGA } \\ \text { U. pugnax } & \text { CCGGGCCCACGCGGTTCGCCGCTGGGCATTCGGCGCCTCGAGCTGACGGA } \\ \text { U. pugilator } & \text { CCGGGCCCACGCGGTTCGCCGCTGGGCATTCGGCGCCTCGAGCTGACGGA }\end{array}$

U. minax AAGATGTCCAAACTTGATCATTTAGAGGAAGTAAAAGTCGTAACAAGGTT U. pugnax AAGATGTCCAAACTTGATCATTTAGAGGAAGTAAAAGTCGTAACAAGGTT U. pugilator AAGATGTCCAAACTTGATCATTTAGAGGAAGTAAAAGTCGTAACAAGGTT

U. minax TCCGTAGGTGAACCTGCGGAAGGATCATTAACGTGTTCTGCCCTAGGCTG U. pugnax TCCGTAGGTGAACCTGCGGAAGGATCATTAACGTGTTTTGCCCTAGGCCG U. pugilator TCCGTAGGTGAACCTGCGGAAGGATCATTAACGWGTTTTGCCCTAGGCTG

U. minax GCAGGAACCAAA-GCAAAAACTTGCTGGGCGAGGAGTAGTTGGTTAGCGG U. pugnax GCAGAAACCAAAAGCAAAAATTTGCTGGGCRAGGAGTADTTGGTTGGCGG U. pugilator GCAGAAACTCACACC-AAAACTTCCTGGGCGAGGAGCCCCCGSMCAGGCT

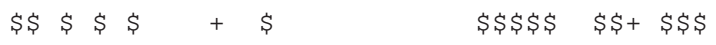

U. minax TCGTCCGAAGTGGTGGTCCGTGCTAGGCTTTCACGGCTGCT-CTCTGGCG U. pugnax TCGTCCAAGGCGGCGGTCCGTGCTAGGCTTTCACGGCTGCTGTTGTGGCG $U$. pugilator TNNNNNNNNNNNNNNNNNNNNNNNNNNNNNNNNNNNNNNNNNNNNNNNNN $\star \star \star * \quad * \star *$

U. minax ACTGYTACCGCTGCTCCTCCGCTTCCCATCCCTTCCTGTCTCCCGTGAGT U. pugnax GCTGCCACCGCTGCTCCTCCGGTTCCCATCCCTTCCTGTCTCCCGTGAGT $U$. pugilator NNNNNNNNNNNNNNNNNNNNNNNNNNNNNNNNNNNNNNNNNNNNNNNNNN

U. minax GTGAGCCAGGCGAGGACTATCTTACGCCGGCGCTGGGTCAGGGGCAGTGT U. pugnax GTGAGCCAGGCGAGGAYTATCTTACGTCGGCGCTGGGTCAGGGGCAGTGT U. pugilator NNNNNNNNNNNNNNNNNNNNNNNNNNNNNNNNNNNNNNNNNNNNNNNNNY

U. minax TTCC-CTGCA--GATATACCGGGCAGAGCTTTCGGTTATCTTACCGTAAC U. pugnax TTCC-CTGCA--TAGATACCGGGCAGAGCATTCGGCTATCTTACCGTAAC U. pugilator TCCACGTCAYTGGGGTT-GGGG-CAGAGC-TTCCYT-TCSGAGCAGAGCA

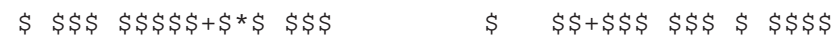

U. mitax CCAC-G--CCACTTTTA-AAC--CTACCCATTCCCCGGGTGTATTACTAC U.pugnax CCAC-G--CCACTTTTA-AAC-CTACCCATTCC-CCGGGTGTATT---AC U. pugilator TTCGGCCCCACGCTGACGACGTTTAAACCTACC-CCGGGTCTAA----AC

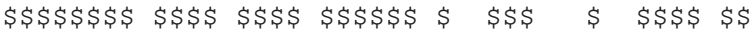

U. minax TCTTTTAAACCCTGTACACTACGC-TTTCCCACATCGTCTCCCGAGGCAG U. pugnax TCTTTTAAACCCTGTACACTACAC-TTTCCCACATCGTCTCCCGAGGCAG U. pugilator TGGTTAAACCCTW-AACACTACGTATTCCCCACATCGTCTCCCGAGGCAG $\$ \$ \$ \$ \$ \$ \quad+\$ \$$

U. minax AGGCGGCGGAAAGTCTTGT--G--GGCACCGCCCGACGT U. pugnax AGGCGGCGGAAAGTCTTGTC----GGCACCGTCCGACGT U. pugilator AGACGGCGGAATGTCTTGTCAGTCGGCAGCGTCCGACGT
$\$$
Site descriptions. Field work was conducted at 3 locations in the North Inlet/Winyah Bay National Estuarine Research Reserve (NERR) at the Baruch Marine Field Laboratory (BMFL) in Georgetown, South Carolina from June to August 2003. Each site had both $S$. alterniflora-covered habitat with UCa pugnax adults and open (sandier, non-vegetated) habitat with U. pugilator adults. Adults of both species were abundant at all sites: Bly Creek (33¹9'36.4" N, 79०12' 21.0" W), Oyster Landing $\left(33^{\circ} 20^{\prime} 58.7^{\prime \prime} \mathrm{N}, 79^{\circ} 11^{\prime} 19.6^{\prime \prime} \mathrm{W}\right)$, and Clambank Creek (3320'04.5" N, 79॰11'42.1"W) (Fig. 2). The Bly Creek sampling site is located $0.57 \mathrm{~m}$ above mean low water (MLW) (slope of $0.63^{\circ}, 36.4 \mathrm{~m}$ distance to adjacent creek at high tide), and is submerged only during storm events and spring tides. Oyster Landing is a gradually sloping $\left(0.39^{\circ}\right)$ shoaled oyster bed located $0.12 \mathrm{~m}$ above MLW, and is adjacent to Crabhaul Creek; this site was completely submerged during all semidiurnal high tides throughout this study. The Clambank Creek sampling site is $1.13 \mathrm{~m}$ above MLW, $18.6 \mathrm{~m}$ from its adjacent creek at high tide, and has the greatest slope of the 3 sites $\left(0.95^{\circ}\right)$. This site is submerged during all high tides, but not as deeply as Oyster Landing.

Sample collection and treatment. Postlarval and juvenile Uca pugnax and $U$. pugilator were collected along transects at each of the 3 sampling sites in the summer of 2003. Each site contained both an open area occupied by adult $U$. pugilator and an area covered with Spartina alterniflora (Figs. 3 \& 4) where $U$. pugnax adults dominated. At each site, a boardwalk of $5 \times 10 \mathrm{~cm}$ supports bearing $5 \times 20 \mathrm{~cm}$ planks extended for $\sim 12.8 \mathrm{~m}(6.4 \mathrm{~m}$ in the open habitat and $6.4 \mathrm{~m}$ in the $S$. alterniflora habitat). The supports of the boardwalks were permanent, but 


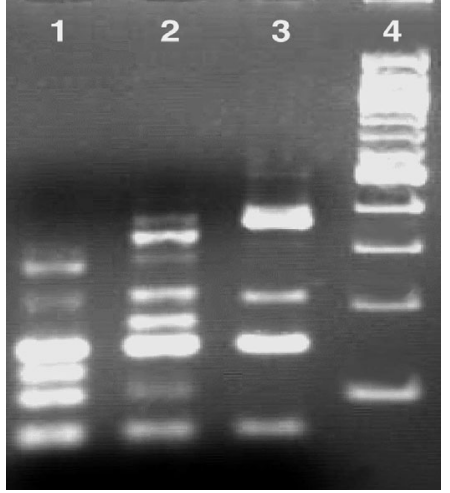

Fig. 1. UCa spp. Image of $3 \%$ agarose restriction digest gel showing distinct banding patterns for $U$. pugnax (Lane 1), $U$. minax (Lane 2), and U. pugilator (Lane 3). Lane 4: 100 bp ladder

not the planks. Regular movement of both crab species throughout the habitats was not impeded by the boardwalk structures at any site. Quadrats of $100 \mathrm{~cm}^{2}$ were positioned at $2 \mathrm{~m}$ intervals, beginning at the transition between both habitats (mid position), and extending in opposite directions (Fig. 4).

All megalopae, 5th instar, crabs found inside the quadrats were collected and preserved in 90\% ethanol. Both megalopae and the juvenile crab stages (1 to 5) were easily spotted on the substratum and collected with a spoon. Crabs were categorized by size (carapace width) as small (megalopa to $1.35 \mathrm{~mm}$ ), medium (1.36 to

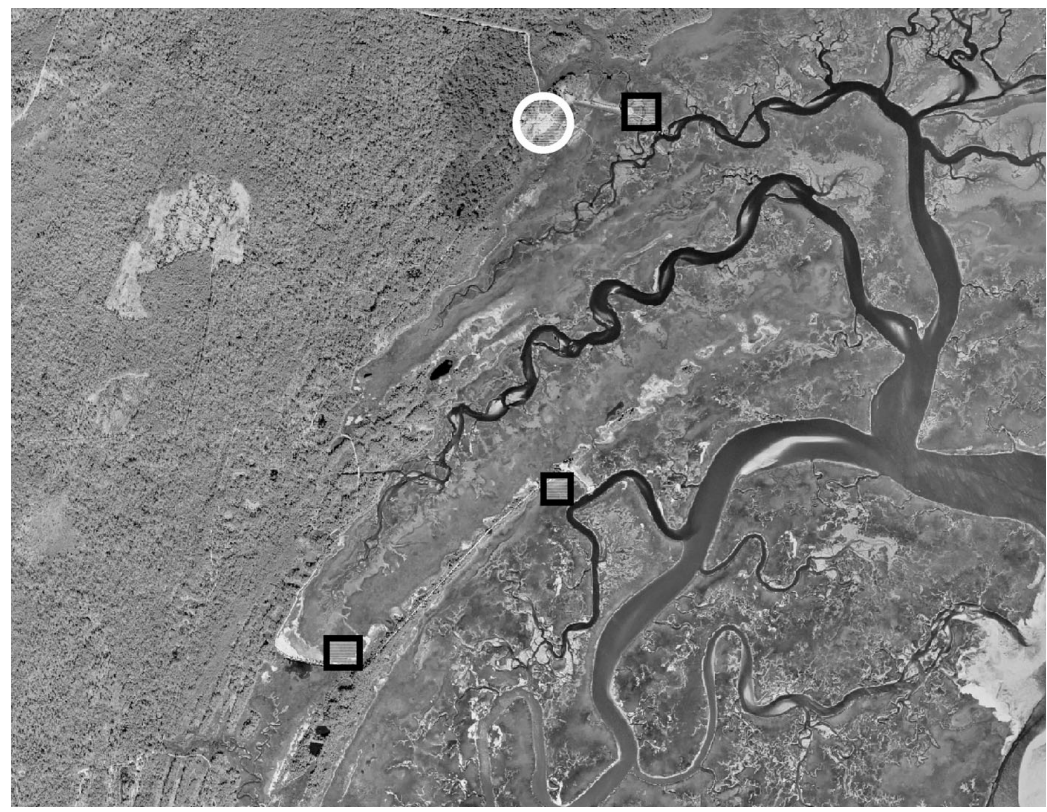

Fig. 2. Satellite image of Baruch Marine Field Laboratory, BMFL (encircled) adjacent to North Inlet Estuary in Georgetown, South Carolina, showing 3 sampling sites (boxes) where Uca spp. juveniles were collected from June to August 2003. From top to bottom sites are: Oyster Landing, Clambank Creek, and Bly Creek (Courtesy of Laura Schmidt of BMFL)
$2.1 \mathrm{~mm}$ ) and large (2.15 to $4.2 \mathrm{~mm})$. The 'small' category comprised early settlers, probably younger than the 2nd instar, the 'medium' category comprised intermediate juveniles younger than the 4th instar, and 'large' crabs comprised later-stage juveniles older than the 3rd instar. All sites were visited twice a week, every 2 wk for 3 tidal cycles during June to August 2003. Sediment temperature and moisture were measured along all 7 sampling locations at every site during each visit. Sediment temperature at each sampling location was recorded as the mean of both sides of the transects with an Omega Utility thermocouple handle probe and accompanying digital thermometer. Sediment moisture was measured gravimetrically: wet surface sediment was collected on one side of the transect planks in film canisters ( 40 to $70 \mathrm{~g}$ total mass), placed in pre-weighed foil boats, and then dried in a Fisher ${ }^{\circledast}$ Isotemp 500 Series, Model 526G oven set at $60^{\circ} \mathrm{C}$ for at least $24 \mathrm{~h}$. Dried sediment was re-weighed on a Sartorius ${ }^{\circledR}$ B120S balance accurate to $0.0001 \mathrm{~g}$.

Statistical analyses. Mean surface-sediment moisture between Spartina alterniflora and open habitats for all sites were compared via 2-sided $t$-tests assuming equal variance (Microsoft Excel XP). Paired $t$-tests compared surface-sediment temperature between $S$. alterniflora and open habitats using SAS Enterprise Guide, Version 1.3 to compensate for the effects of diurnal variation on temperature measurements. Correlations between crab size and percent sediment moisture and surface sediment temperature were performed using Microsoft Excel. Chi-square goodness of fit tests analyzed specific differences in distribution across habitat type. Power analyses were performed using GPOWER (Erdfelder et al. 1996).

\section{RESULTS}

\section{Juvenile crab abundance across habitat types}

Juvenile crabs were most abundant at Clambank Creek, and Uca pugnax was more common than $U$. pugilator at all 3 sites, comprising $>75 \%$ of the 821 juvenile crabs we collected and identified (Table 2). U. pugnax were 3.8 to 14.6 times more abundant in $S$. alterniflora-covered than in the open habitat. Only $23 U$. pugilator were collected at Bly Creek over the entire sampling period, so habitat comparisons are difficult to make. $U$. pugilator 
Table 2. Uca spp. Density (mean $\pm \mathrm{SD}$ ind. $\mathrm{m}^{-2}$ ) of juvenile (megalopa, $4.2 \mathrm{~mm}$ carapace width) U. pugnax and U. pugilator and total numbers collected in 3 habitat types at all 3 sites studied in Horth Inlet estuary; a total of 6 quadrats were sampled in open and covered habitats, and 2 in mid habitat (transition between open and covered). Oyster Landing site had 9 total sampling periods, the other 2 sites were visited 8 times

\begin{tabular}{|c|c|c|c|c|}
\hline \multirow[t]{2}{*}{ Species } & \multicolumn{3}{|c|}{ Habitat type } & \multirow{2}{*}{$\begin{array}{c}\text { Tota } \\
\mathrm{N}\end{array}$} \\
\hline & Open & Mid & Covered & \\
\hline \multicolumn{5}{|l|}{ Bly Creek } \\
\hline U. pugnax & $\begin{array}{c}58 \pm 37 \\
(\mathrm{~N}=28)\end{array}$ & $\begin{array}{l}138 \pm 91 \\
(\mathrm{~N}=22)\end{array}$ & $\begin{array}{c}350 \pm 97 \\
(\mathrm{~N}=168)\end{array}$ & 218 \\
\hline U. pugilator & $\begin{array}{l}15 \pm 18 \\
(\mathrm{~N}=7)\end{array}$ & $\begin{array}{l}38 \pm 35 \\
(\mathrm{~N}=6)\end{array}$ & $\begin{array}{c}21 \pm 46 \\
(\mathrm{~N}=10)\end{array}$ & 23 \\
\hline Total & 35 & 28 & 178 & 241 \\
\hline \multicolumn{5}{|c|}{ Oyster Landing } \\
\hline U. pugnax & $\begin{array}{c}74 \pm 60 \\
(\mathrm{~N}=40)\end{array}$ & $\begin{array}{l}100 \pm 79 \\
(N=18)\end{array}$ & $\begin{array}{c}280 \pm 91 \\
(N=151)\end{array}$ & 209 \\
\hline U. pugilator & $\begin{array}{c}33 \pm 19 \\
(N=18)\end{array}$ & $\begin{array}{l}44 \pm 39 \\
(\mathrm{~N}=8)\end{array}$ & $\begin{array}{c}61 \pm 62 \\
(\mathrm{~N}=33)\end{array}$ & 59 \\
\hline Total & 58 & 26 & 184 & 268 \\
\hline \multicolumn{5}{|c|}{ Clambank Creek } \\
\hline U. pugnax & $\begin{array}{c}25 \pm 38 \\
(N=12)\end{array}$ & $\begin{array}{l}125 \pm 84 \\
(\mathrm{~N}=20)\end{array}$ & $\begin{array}{c}365 \pm 76 \\
(N=175)\end{array}$ & 207 \\
\hline U. pugilator & $\begin{array}{l}121 \pm 89 \\
(N=58)\end{array}$ & $\begin{array}{c}125 \pm 136 \\
(\mathrm{~N}=20)\end{array}$ & $\begin{array}{c}56 \pm 98 \\
(N=27)\end{array}$ & 105 \\
\hline Total & 70 & 40 & 202 & 312 \\
\hline Overall total & 163 & 94 & 564 & 821 \\
\hline
\end{tabular}

density gradually increased from the open to covered habitats at Oyster Landing, but was higher in the open and mid habitats than in covered locations at Clambank Creek.

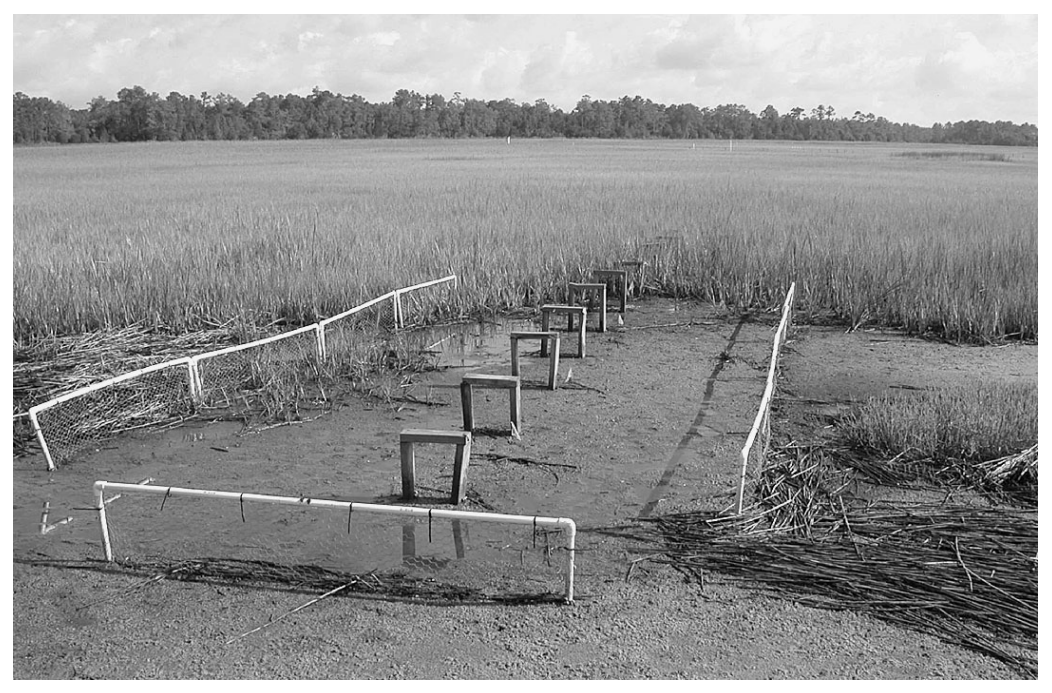

Fig. 3. A sampling site (near Bly Creek). Sampling sites span open, sandy habitat and muddier habitat covered with Spartina alterniflora. Fences surrounding this site prevented dead wrack from floating into the sampling site during very high tide; fences were not necessary at Oyster Landing or Clambank Creek. Boardwalk supports are shown, removable planks are not present

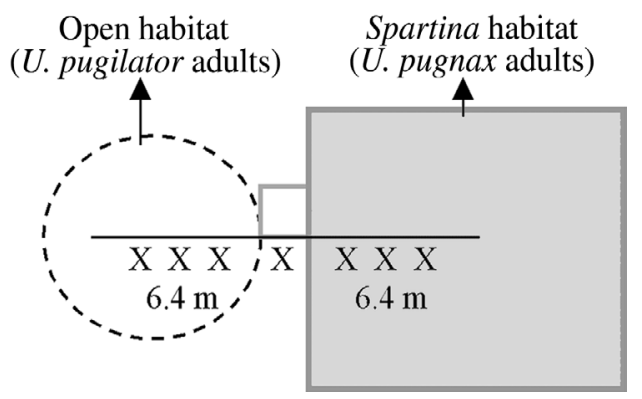

Fig. 4. Diagram of transect between open habitat and Spartina alterniflora-covered habitat. Open habitat at each site was at least $6.4 \mathrm{~m}$ radius distant from adjacent $S$. alterniflora habitat, which was variable in area, but at least equal to general dimensions of the open habitat. At each sampling location, a transect (continuous line) was centered between peripheries of open habitat and $S$. alterniflora habitat (shaded square) and continued for $6.4 \mathrm{~m}$ in opposite directions, with a total transect length of $12.8 \mathrm{~m}$. X = sampling locations spaced at $2 \mathrm{~m}$ intervals: there were a total of 7 sampling locations per site, with 2 quadrats per sampling station

\section{Juvenile crab distribution by size across habitat types}

At Bly Creek, juvenile Uca pugnax of all sizes were significantly more abundant in covered than in open habitats, although the later stages were more widely distributed ( $\mathrm{p}<0.05$, small: $\chi^{2}{ }_{[1]}=31.0$; medium: $\chi_{[1]}^{2}=$ 48.3; large: $\chi_{[1]}^{2}=27.2$; Fig. 5). The abundance of $U$. pugilator at Bly Creek was too low for analysis.

At Oyster Landing, small UCa pugnax $\left(\chi_{[1]}^{2}=40.0\right)$ and $U$. pugilator $\left(\chi_{[1]}^{2}=5.76\right)$ were more abundant in the covered habitat ( $p<0.05$, Fig. 6). Medium $U$. pugnax were more abundant in the covered habitat $(\mathrm{p}<0.05$, $\left.\chi_{[1]}^{2}=28.4\right)$. Although medium and large juvenile $U$. pugilator and large U. pugnax appeared to be evenly distributed across open and Spartina alterniflora-covered habitats (Fig. 6), too few specimens were collected for rigorous statistical analysis (power $<0.22$ ).

At Clambank Creek, small Uca pugnax were more abundant in the covered habitat $\left(p<0.05, \chi_{[1]}^{2}=43.0\right.$, Fig. 7). Small U. pugilator were most abundant in the transition zone between open and Spartina alterniflora-covered areas, however the power was too low (0.120) to analyze this distribution statistically. Medium U. pugnax were more abundant in the covered habitat $\left(p<0.05, \chi_{[1]}^{2}=66.1\right)$, while $U$. pugilator were more abundant in the open habitat $(\mathrm{p}<0.05$, 


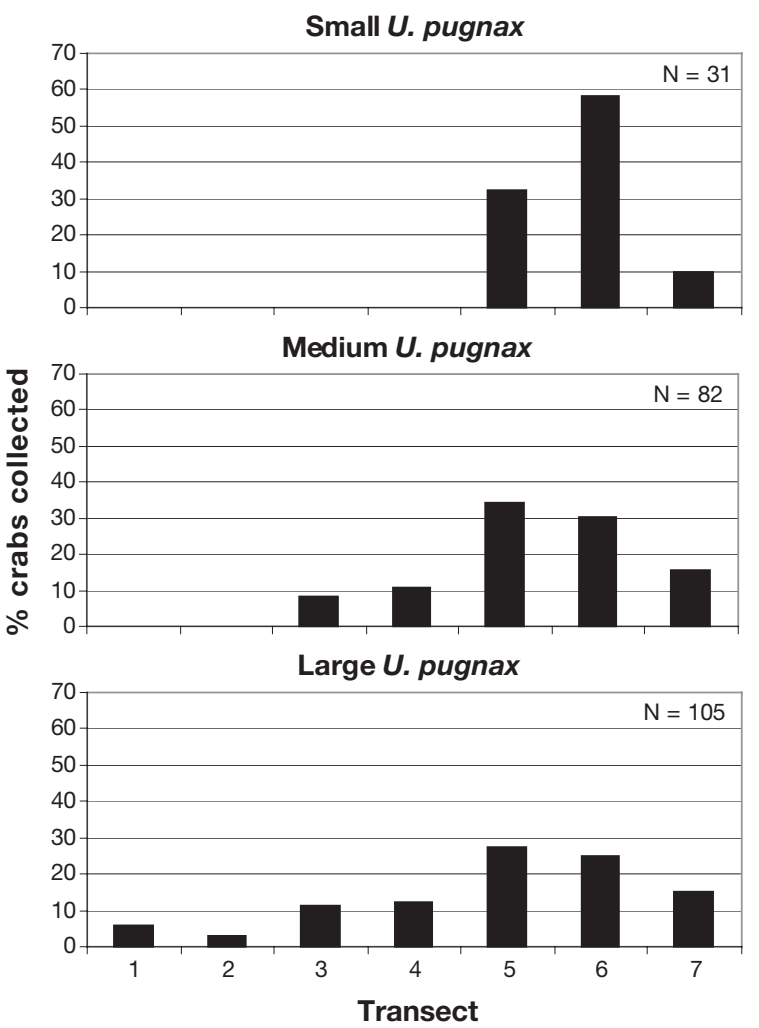

Fig. 5. Uca pugnax. Percent total small (megalopa to $1.35 \mathrm{~mm}$ ), medium (1.36 to $2.1 \mathrm{~mm}$ ) and large (2.15 to $4.22 \mathrm{~m}$ ) juveniles collected across transects at Bly Creek. Transects 1 to 3: open habitat; Transect 4: transition zone; Transects 5 to 7 : Spartina alterniflora-covered habitat $\left.\chi_{[1]}^{2}=6.13\right)$. Large $U$. pugnax were more abundant in the covered habitat $\left(\mathrm{p}<0.05, \chi_{[1]}^{2}=41.7\right)$, while $U$. pugilator were more abundant in the open habitat $\left(\mathrm{p}<0.05, \chi_{[1]}^{2}=19.2\right)$.

\section{Sediment temperature, water content, and Uca spp. distribution}

There was no significant difference between the surface-sediment temperature in open and covered habitats at Bly Creek ( $p=0.13$ ) and Oyster Landing ( $p=0.86$ ), but the open habitat was warmer than the covered habitat at Clambank Creek ( $p=0.003$, Fig. 8), Percent sediment water content in covered habitats was higher than in the open habitat at all sites ( $p<0.001$, Fig. 9). No correlations were found between juvenile size and surface sediment temperature or water content for any site.

\section{DISCUSSION}

Uca pugnax were at least twice as abundant as $U$. pugilator at our sampling sites in the North Inlet Estuary. This discrepancy was especially noticeable at the Bly Creek site, where only 23 juvenile U. pugilator were collected compared to more than 200 U. pugnax. Bly Creek sediment was the driest of the 3 sampling sites, and this site was rarely submerged during high

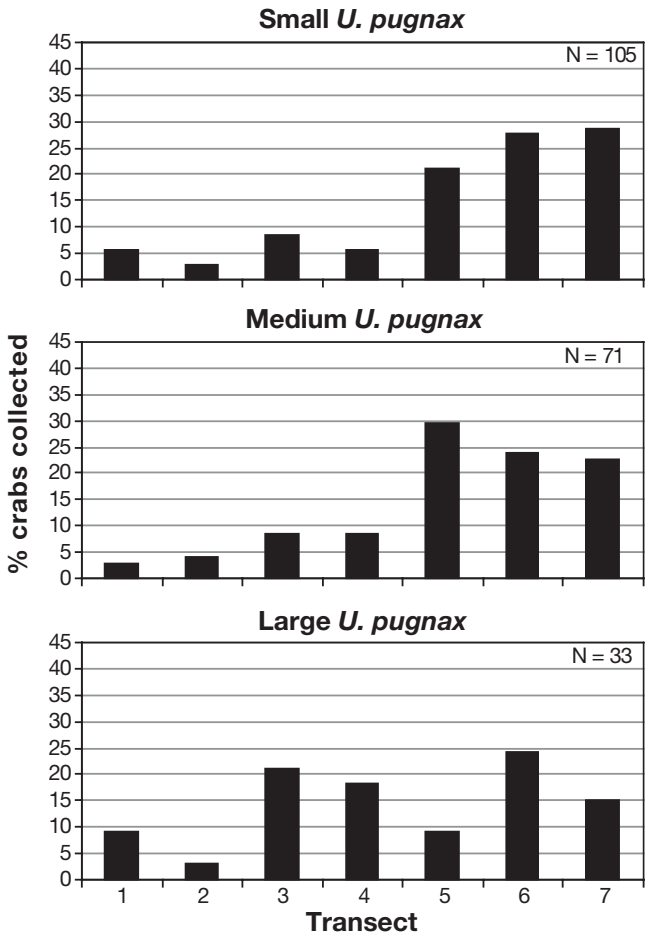

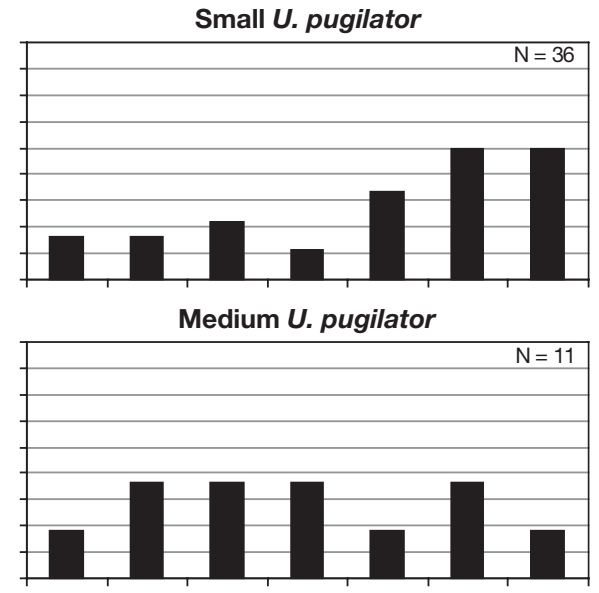

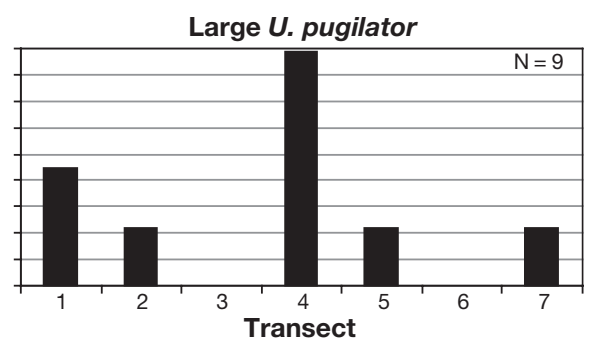

Fig. 6. Uca pugnax and U. pugilator. Percent total small, medium, and large juveniles collected across transect position at Oyster Landing. Transects as in Fig. 5 

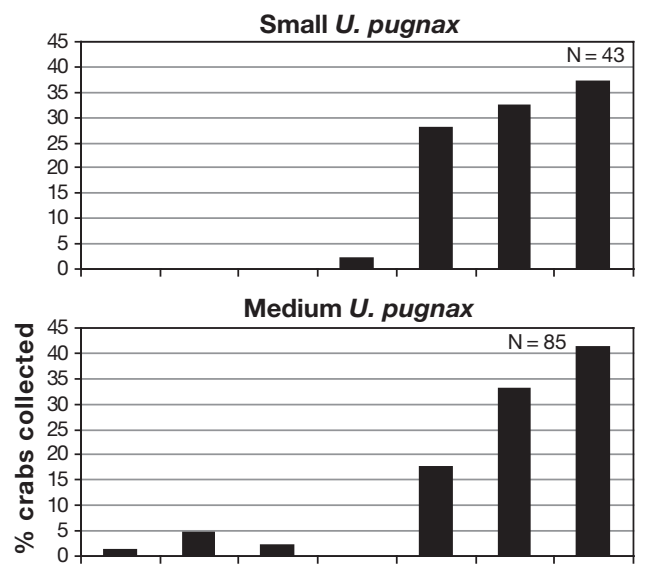

Large U. pugnax

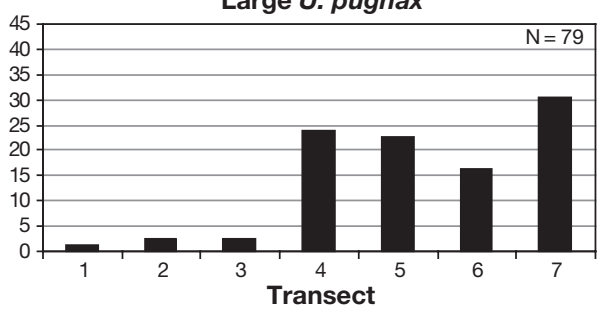

Bly Creek
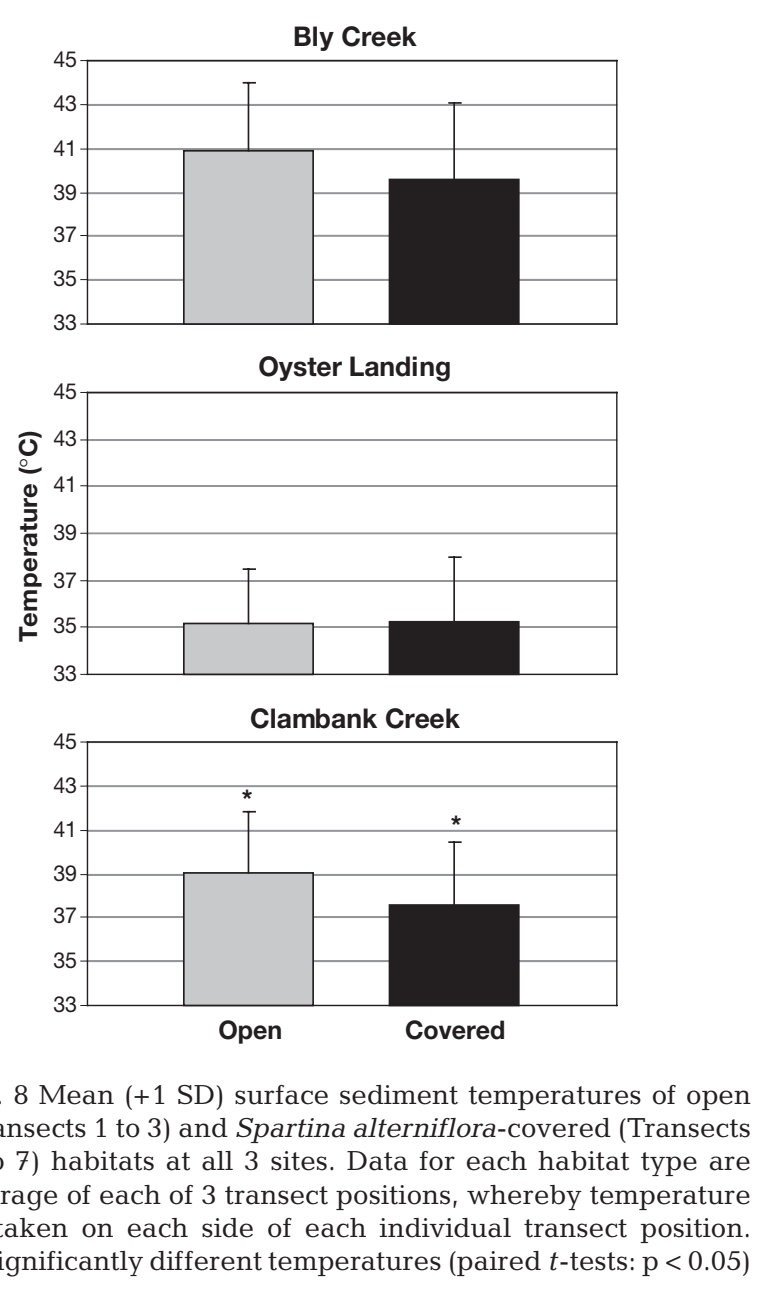

Fig. 8 Mean $(+1 \mathrm{SD})$ surface sediment temperatures of open (Transects 1 to 3) and Spartina alterniflora-covered (Transects 5 to 7 ) habitats at all 3 sites. Data for each habitat type are average of each of 3 transect positions, whereby temperature as taken on each side of each individual transect position. *: significantly different temperatures (paired $t$-tests: $\mathrm{p}<0.05$ )
Fig. 7. Uca pugnax and U. pugilator. Percent total small, medium, and large juveniles collected across transect position at Clambank Creek. Transects as in Fig. 5
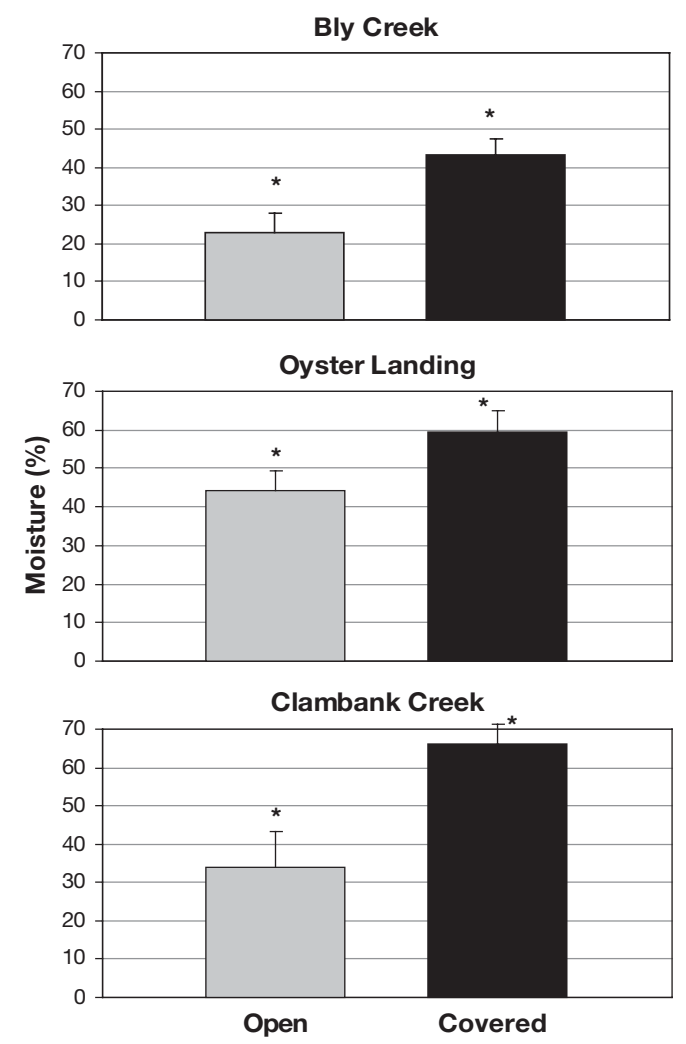

Fig. 9. Mean (+1 SD) percent moisture in sediment of open (Transects 1 to 3) and Spartina alterniflora-covered (Transects 5 to 7 ) habitats at all 3 sites. Data for each habitat type are average of initial sediment mass comprised by water. All sites had significantly greater moisture in 'covered' than in 'open' habitats $(p<0.0001$ indicated by *) 
tide, although specific reasons for this are unknown. It is possible that $U$. pugilator juveniles did not successfully recruit at Bly Creek due to a lack of a strong cue, or perhaps $U$. pugilator postlarvae were low in abundance in the water column during flooding events. Postlarvae densities were not observed for adjacent tidal creeks at any site.

The distributions patterns of juvenile Uca pugnax across habitat types were consistent at each site, but this was not true for $U$. pugilator. $U$. pugnax juveniles were most abundant in Spartina alterniflora-covered habitat with muddier sediment at all 3 sites where adults of this species were common. Generally younger $U$. pugilator juveniles did not prefer the open habitat where adults of this species live but, instead, the smallest individuals were in either a covered habitat or the transition zone; the crabs began occupying the open habitat at larger sizes. O'Connor (1993) observed all stages of juvenile $U$. pugilator in a sandy, open habitat nearest the adjacent tidal creek. In contrast, we found variation between sites in the distribution of juvenile $U$. pugilator.

At Clambank Creek, most of the youngest $U_{C a}$ pugilator juveniles were generally found in the transitional zone, but larger juveniles were more common in the sandier, open habitat. Clambank Creek was not submerged as deeply as Oyster Landing, and U. pugilator juveniles may have experienced less predation pressure from aquatic predators at the Clambank Creek site, enabling them to shift to the adult habitat at a smaller size compared to those at Oyster Landing. Fishes and shrimp could more regularly prey on juvenile Uca spp. in the open habitat without the protection of vegetation to conceal juvenile crabs during daily submergence $<0.914 \mathrm{~m}$ by semidiurnal high tides (Kneib \& Stiven 1978, Hettler 1989). This is especially true for younger juveniles, because Uca spp. are unable to dig burrows for protection until the 3rd to 5th instar (Herrnkind 1968), which was the 'large' size category in the present study. Larger juveniles of both species were observed in the open habitats at Bly Creek and Clambank Creek (not Oyster Landing), supporting the idea that juvenile Uca spp. are able to exploit more exposed habitats once they have developed the ability to dig burrows.

Moisture and temperature differences did not explain the distribution of Uca spp. across habitat types. Another potential factor is food type, and the ability to process this food. Adults of both species are normally segregated by sediment grain size- $U$. pugilator prefers sandy substrate, $U$ pugnax prefers muddier sediment (Teal 1958, Crane 1975, Reinsel \& Rittschof 1995). Furthermore, U. pugilator adults scrape organic matter off sediment grains via the spoon-tipped setae on the meropodite of their second maxillipeds, while $U$. pugnax do not possess these specialized setae (O'Connor 1990a). It is not until the 5th or 6th instar that juvenile $U$. pugilator develop the setae appropriate for organic matter consumption from sandier substrate (Crane 1975). Younger instars may settle in the covered, muddier habitat, where grain sizes are smaller so that they can efficiently consume the organic matter necessary for survival.

Cannibalism of Uca spp. larvae and early juveniles by conspecific adults has also been observed in the laboratory (O'Connor 1990b). By settling outside the conspecific adult habitat, within greater Spartina alterniflora cover, $U$. pugilator may obtain some protection from adults of their own species, but not from U. pugnax adults. By settling in areas with $S$. alterniflora cover, U. pugilator juveniles may also reduce their exposure to predators that forage during low tides, such as birds, worms and other crab species.

Our results compare favorably with those of previous settlement studies of motile invertebrates. Like Uca pugnax, other crustaceans, including Carcinus maenas (Klein Breteler 1976), Callinectes sapidus (Orth \& van Montfrans 1987), Panulirus argus (Marx \& Herrnkind 1985, Herrnkind \& Butler 1986), and Homarus americanus (Hudon 1987, Wahle \& Steneck 1991, 1992) settle directly into conspecific adult habitats (albeit, microhabitats within the general adult habitat). Like $U$. pugilator, the sea hare Aplysia juliana (Sarver 1979) and snail Littorina neritoides (Fretter \& Manly 1977) settle primarily away from the conspecific adult habitat in order to feed and grow, followed by eventual migration to the adult habitat.

The results from this study expand our presently limited information on the horizontal movement of UCa spp. juveniles throughout adult habitats in the salt marsh. Much remains to be discovered about the possible effects of both aquatic and terrestrial predators on juvenile fiddler crab settlement, recruitment, and distribution throughout intertidal habitats. We think it important to conduct such studies in many locations within a marsh that varies in its proximity to tidal creeks, its slope to tidal creeks, and the frequency of site submergence, since broad generalizations from individual sampling sites may be misleading. The application of RFLP will greatly increase the efficiency with which these and related uncertainties can be addressed. The technique is an efficient, easy way of identifying to species hundreds to thousands of crabs without the necessity of rearing them to a size at which they can be identified morphologically.

Acknowledgements. This work was supported by the National Science Foundation (NSF IBN-0237484), and represents manuscript No. 1398 of the Baruch Marine Field Laboratory (BMFL). Thanks are due to D. Wethey and K. Nelson for primary manuscript revisions, and to J. Christy for sec- 
ondary revisions. E. Monroe helped develop the RFLP protocol. S. Jones also assisted in sample processing during the development of the RFLP protocol. K. Butler and J. Wiggins assisted me during the summer of 2003 with field site construction, sample collection, and sample processing. Thanks are extended to L. Schmidt and P. Kenny of BMFL for helping with satellite imagery and field site selections. J. EmordGodley of the Brodie Laboratory Group assisted with laboratory processing and field work.

\section{LITERATURE CITED}

Christy JH (1982) Adaptive significance of semilunar cycles of larval release in fiddler crabs (Genus $U_{C a}$ ): test of an hypothesis. Biol Bull (Woods Hole) 163:251-263

Christy JH (1989) Rapid development of megalopae of the fiddler crab Uca pugilator reared over sediment: Implications for models of larval recruitment. Mar Ecol Prog Ser 57: 259-265

Christy JH, Morgan SG (1998) Estuarine immigration by crab postlarvae: mechanics, reliability, and adaptive significance. Mar Ecol Prog Ser 174:51-65

Christy JH, Stancyk SE (1982) Tuning of larval production and flux of invertebrate larvae in a well-mixed estuary. In: Kennedy VS (ed) Estuarine comparisons. Academic Press, New York, p 489-503

Crane J (1975) Fiddler crabs of the world. Princeton University Press, Princeton, NJ

Epifanio CE, Little KT, Rowe PM (1988) Dispersal and recruitment of fiddler crab larvae in the Delaware River estuary. Mar Ecol Prog Ser 43:181-188

Erdfelder E, Faul F, Buchner A (1996) GPOWER: a general power analysis program. Behav Res Meth Instrum Comput 28:1-11

Fretter V, Manly R (1977) The settlement and early benthic life of Littorina neritoides (L.) at Wernbury, S. Devon. J Molluscan Stud 43:255-262

Frix MS, Hostetler ME, Bildstein KL (1991) Intra- and interspecies differences in responses of Atlantic sand (UCa pugilator) and Atlantic marsh (U. pugnax) fiddler crabs to simulated avian predators. J Crustac Biol 11:523-529

Hadfield MG (1986) Settlement and recruitment of marine invertebrates: A perspective and some proposals. Bull Mar Sci 39:418-425

Herrnkind WF (1968) The breeding of Uca pugilator (Bosc) and mass rearing of the larvae with comments on the behavior of the larval and early crab stages (Brachyura, Ocypodidae). Crustac Suppl 2:214-224

Herrnkind WF, Butler MJ IV (1986) Factors regulating postlarval settlement and juvenile microhabitat use by spiny lobsters Panulirus argus. Mar Ecol Prog Ser 34:23-30

Hettler WF Jr (1989) Nekton use of regularly-flooded saltmarsh cordgrass habitat in North Carolina, USA. Mar Ecol Prog Ser 56:111-118

Houser DS, Allen DM (1996) Zooplankton dynamics in an intertidal salt-marsh basin. Estuaries 19:659-673

Hudon C (1987) Ecology and growth of postlarval and juvenile lobster, Homarus americanus, off Iles de la Madeleine (Quebec). Can J Fish Aquat Sci 44:1855-1869

Hunter J, Feller RJ (1987) Immunological dietary analysis of two penaeid shrimp species from a South Carolina tidal creek. J Exp Mar Biol Ecol 107:61-70

Johnson WS, Allen DM, Ogburn MV, Stancyk SE (1990) Short-term predation responses of adult bay anchovies Anchoa mitchilli to estuarine zooplankton availability. Mar Ecol Prog Ser 64:55-68
Jones MB, Epifanio CE (1995) Settlement of brachyuran megalopae in Delaware Bay: an analysis of time series data. Mar Ecol Prog Ser 125:67-76

Klein Breteler WCM (1976) Settlement, growth and production of the shore crab, Carcinus maenas, on tidal flats in the Dutch Wadden Sea. Neth J Sea Res 10:354-376

Kneib RT, Stiven AE (1978) Growth, reproduction, and feeding of Fundulus heteroclitus (L.) on a North Carolina salt marsh. J Exp Mar Biol Ecol 31:121-140

Kusukawa N, Uemori T, Asada K, Kato 1 (1990) Rapid, reliable protocol for direct sequencing of material amplified by the PCR. Biotechniques 9:66-72

Land M, Layne J (1995) The visual control of behaviour in fiddler crabs. 2. Tracking control systems in courtship and defence. J Comp Physiol 177:91-103

Levinton JS, Judge ML (1993) The relationship of closing force to body size for the major claw of Uca pugnax (Decapoda: Ocypodidae). Funct Ecol 7:339-345

Mangum CP (1993) Structural and functional polymorphism of the hemocyanin $\mathrm{O}_{2}$ transport system of the sand fiddler crab Uca pugilator. J Exp Mar Biol Ecol 165:133-141

Marx JM, Herrnkind WF (1985) Macroalgae (Rhodophyta: Laurencia spp.) as habitat for young juvenile spiny lobsters, Panuffrus argus. Bull Mar Sci 36:423-431

Montague CL (1982) The influence of fiddler crab burrows and burrowing on metabolic processes in salt marsh sediments. In: Kennedy VS (ed) Estuarine comparisons. Academic Press, New York, p 283-301

O'Connor NJ (1990a) Morphological differentiation and molting of juvenile fiddler crabs (UCa pugilator and U. pugnax). J Crustac Biol 10:608-612

O'Connor NJ (1990b) Larval settlement and juvenile recruitment in fiddler crab populations. PhD dissertation, North Carolina State University, Raleigh, NC

O'Connor NJ (1991) Flexibility in timing of the metamorphic molt by fiddler crab megalopae Uca pugilator. Mar Ecol Prog Ser 68:243-247

O'Connor NJ (1993) Settlement and recruitment of the fiddler crabs Uca pugnax and U. pugilator in a North Carolina, USA salt marsh. Mar Ecol Prog Ser 93:227-234

O'Connor NJ, Gregg AS (1998) Influence of potential habitat cues on duration of the megalopal stage of the fiddler crab Uca pugnax. J Crustac Biol 18:700-709

O'Connor NJ, Judge ML (1999) Cues in salt marshes stimulate molting of fiddler crab Uca pugnax megalopae: more evidence from field experiments. Mar Ecol Prog Ser 181: 131-139

Orth RJ, van Montfrans J (1987) Utilization of a seagrass meadow and tidal marsh creek by blue crabs Callinectes sapidus. I. Seasonal and annual variations in abundance with emphasis on post-settlement juveniles. Mar Ecol Prog Ser 41:283-294

Palmer JD (1989) Comparative studies of tidal rhythms. 7. The ciralundian locomotor rhythm of the brackish-water fiddler crab, Uca minax. Mar Behav Physiol 14:129-143

Petit DR, Bildstein KL (1987) Effect of group size and location within the group on the foraging behavior of white ibises. Condor 89:602-609

Reddy PS, Fingerman M (1995) Effect of cadmium chloride on physiological color changes of the fiddler crab, Uca pugilator. Ecotoxicol Environ Saf 31:69-75

Reinsel KA, Rittschof D (1995) Environmental regulation of foraging in the sand fiddler crab Uca pugilator (Bosc 1802). J Exp Mar Biol Ecol 187:269-287

Saiki RK, Gelfand DH, Stoffel S, Scharf SJ, Higuchi R, Horn GT, Mullis KB, Erlich HA (1988) Primer-directed enzymaitic amplification of DNA with a thermostable DNA 
polymerase. Science 239:487-491

Sandifer PA (1973) Distribution and abundance of decapod crustacean larvae in the York River estuary and adjacent lower Chesapeake Bay, Virginia, 1968-1969. Chesapeake Sci 14:235-257

Sarver DJ (1979) Recruitment and juvenile survival in the sea hare Aplysia juliana (Gastropoda: Opisthobranchia). Mar Biol 54:353-361

Schizas NV, Street GT, Coull BC, Chandler GT, Quattro JM (1999) Molecular population structure of the marine benthic copepod Microarthridion littorale along the southeastern and Gulf coasts of the United States. Mar Biol 135: 399-405

Teal JM (1958) Distribution of fiddler crabs in Georgia salt marshes. Ecology 39:185-193

Thurman C (2002) Osmoregulation in six sympatric fiddler crabs (genus $U_{C a}$ ) from the northwestern Gulf of Mexico.

Editorial responsibility: Otto Kinne (Editor-in-Chief), Oldendorf/Luhe, Germany
PSZN I: Mar Ecol 23:269-284

Thurman C (2003) Osmoregulation by six species of fiddler crabs (Uca) from the Mississippi delta area in the northern Gulf of Mexico. J Exp Mar Biol Ecol 4154:1-21

Wahle RA, RS Steneck (1991) Recruitment habitats and nursery grounds of the American lobster Homarus americanus: a demographic bottleneck? Mar Ecol Prog Ser 69:231-243

Wahle RA, Steneck RS (1992) Habitat restrictions in early benthic life: experiments on habitat selection and in situ predation with the American lobster. J Exp Mar Biol Ecol $157: 91-114$

Watts BD (1988) Foraging implications of food usage patterns in yellow-crowned night herons. Condor 90:860-865

Winger PV, Schultz DP, Johnson WW (1990) Environmental contaminant concentrations in biota from the lower Savannah River, Georgia and South Carolina. Arch Environ Contam Toxicol 19:101-117

Submitted: May 25, 2004; Accepted: November 2, 2004 Proofs received from author(s): February 28, 2005 